\title{
Ethnologies
}

\section{Alaska's Daughter: An Eskimo Memoir of the Early Twentieth Century. By Elizabeth Bernhardt Pinson, foreword by Bret Corrington. (Logan: Utah State University Press, 2004. Pp. x + 212, maps, photographs, ISBN 0-87421-591-9)}

\section{Vasiliki Douglas}

Volume 29, numéro 1-2, 2007

Retour à l'ethnographie

Back to Ethnography

URI : https://id.erudit.org/iderudit/018762ar

DOI : https://doi.org/10.7202/018762ar

Aller au sommaire du numéro

Éditeur(s)

Association Canadienne d'Ethnologie et de Folklore

ISSN

1481-5974 (imprimé)

1708-0401 (numérique)

Découvrir la revue

Citer ce compte rendu

Douglas, V. (2007). Compte rendu de [Alaska's Daughter: An Eskimo Memoir of the Early Twentieth Century. By Elizabeth Bernhardt Pinson, foreword by Bret Corrington. (Logan: Utah State University Press, 2004. Pp. x + 212, maps, photographs, ISBN 0-87421-591-9)]. Ethnologies, 29(1-2), 366-368.

https://doi.org/10.7202/018762ar d'utilisation que vous pouvez consulter en ligne. 


\section{Alaska's Daughter: An Eskimo Memoir of the Early Twentieth Century.} By Elizabeth Bernhardt Pinson, foreword by Bret Corrington. (Logan: Utah State University Press, 2004. Pp. $x+212$, maps, photographs, ISBN 087421-591-9)

The period between the gold rush and the Second World War in Alaska and the Canadian Western Arctic is well documented from the transient perspective of the miners, but less well known from the perspective of either the native population or the descendants of intermarriage between settlers and natives.

Elizabeth Pinson's autobiography is the memoir of a child of both the Iñupiat people of the Seward Peninsula and the European immigrants who flooded into the region in the twentieth century. Pinson was one of thirteen children raised in the small community of Teller by an Iñupiat mother and a German father who raised the family on his meagre income from casual work in the mines and hunting and fishing. Thus, she inherited aspects of both traditions. While educated in European culture, especially her father's Roman-Catholic faith, she also received an Iñupiat name, Kiana, from her mother's family. As a child, Pinson spent a considerable amount of time living with her Iñupiat grandparents, who still lived a traditional life on the land and adhered to the Iñupiat shamanistic religion. Her mother, although a Catholic convert and educated at a mission school, also maintained some traditional practices, including belief in Iñupiat spirits and Iñupiat food and eating patterns, which she shared with her children.

Pinson's time with her grandparents also led to the loss of her legs at age six, during the 1918 Influenza Epidemic. She was staying with her grandparents at the time and suffered severe frostbite when they both died and was left alone for two days in severe weather. Although she did survive, both legs had to be amputated. This loss appears to have been something of an opportunity for Pinson as assistance came from a well-off American couple who heard of the tragedy. They provided her with the means to later attend residential school in Seward, Alaska and paid for visits to Seattle to have artificial legs fitted.

Although Pinson was well-travelled for a girl from her modest background, Teller does not appear as isolated as might be assumed. Pinson's childhood included encounters with such luminaries of Arctic exploration as Roald Amundsen, Henry Larsen and Ada Blackjack, sole survivor of the Wrangel Expedition. She also witnessed both the 
RCMP patrol vessel St. Roch on her maiden voyage, and the crash of Amundsen's airship, Norge. If anything, her life appears less interesting after her departure from Teller, although her account of life in a native residential school, the Jesse Lee School in Seward, is a valuable description of what, from Pinson's description, was one of the more pleasant of such institutions. After completing high school there, Pinson married, gave birth to a son, was abandoned by her husband in the Seattle area, and spent most of her adult life struggling to make ends meet by working at a variety of clerical jobs. She is currently living in Seattle.

Alaska's Daughter was compiled from journals Pinson kept from childhood through to at least her graduation from high school. Although there has been considerable editing involved, given that writing the manuscript took twenty years, the events were recorded at the time, and some of the journal entries are presented verbatim. Some of the text added to give a context to events is coloured by retrospective editing, particularly the first chapter's discussion of the impact of disease on the Iñupiat and the early days of the Alaskan gold rush. However, the first hand accounts, such as the 1928 conversation between Pinson's father and Henry Larsen on the social problems attendant on Southern penetration of the Canadian Arctic, are faithful records of events.

Although subtitled an Eskimo memoir, Alaska's Daughter does not reflect an Iñupiat life. While Pinson accepts her Iñupiat heritage as a natural part of her identity, she does not identify herself as Iñupiat. On attending residential school, she is careful to note that anyone with any native blood was entitled to attend, whether or not they were actually native, and that many of the children were offspring of mixed marriages. She distinguishes between these children and the native children, not on racial grounds (some of the "native" children had blond hair, blue eyes and fair skin), but on cultural grounds. The children of mixed marriages were Alaskan and Northern, but not Aleut, Iñupiat or Yup'ik. Although this might now seem grounds to claim that they were suspended between two worlds, that of the Natives and that of the Americans and Europeans, Pinson does not share this perspective either. She clearly believes that she, and other Alaskans like her, are Alaskans: that their identity is securely bound up in the North and their mixed cultural heritage. 
Pinson's memoir records the cultural synthesis that reigned in Alaska during the period between the end of the gold rush and the massive development attendant on the Second World War. As such it reflects the experiences of a group that has received little attention from historians, ethnologists and folklorists, and is now increasingly disappearing. The hybrid culture that produced Elizabeth Pinson is passing, as she herself recognises, and her memoir thus stands as one of their few memorials. Although many Alaskans have native ancestors, few now share Pinson's experience of their traditional culture.

Alaska's Daughter thus stands as both a firsthand record of important events and opinions in Arctic exploration and life, and an insight into Alaskan culture in the early twentieth century. It provides enough context for even novices in Arctic and Alaskan history and ethnography to follow events, and is written in an engaging and pleasant style that reflects Pinson's early experience in journalism at her residential school. Academics will find little new in the historical background, but should find her firsthand accounts of historical events useful and the cultural perspective that emerges from Alaska's Daughter interesting.

Vasiliki Douglas

University of Alberta

Edmonton, Alberta

The Artists of Nathadwara: The Practice of Painting in Rajasthan. By Tryna Lyons. (Mapin: Indian University Press, 2004. Pp 360, photos, ISBN 025334-417-4)

The town of Nathadwara is in the state of Rajasthan, forty-five kilometres west of Udaipur, on the road to Jodhpur and Ajmer. The surrounding land is largely rocky uplands, part of the Aravalli range of hills, and cut by a few narrow, fertile valleys. The town owes its existence almost entirely to its temples and the resulting traffic of pilgrims. The temples in turn owe their attraction mainly to the presence of one particular deity, Shri Nathji, who is the presiding deity of the main temple in Nathadwara. The temples (1670-1672) were built by the Vallabha sampraday sect, after the image of Shri Nathji was transported from Braj, in the state of Uttar Pradesh, where the sect was originally founded two hundred years earlier. 